\title{
sciendo
}

\section{A COMPARISON OF MORPHOMETRIC INDICES, MINERALIZATION LEVEL OF LONG BONES AND SELECTED BLOOD PARAMETERS IN HENS OF THREE BREEDS*}

\author{
Iwona Skomorucha`, Ewa Sosnówka-Czajka \\ Department of Poultry Breeding, National Research Institute of Animal Production, \\ 32-083 Balice n. Kraków, Poland \\ •Corresponding author: iwona.skomorucha@iz.edu.pl
}

\begin{abstract}
The aim of the study was to compare morphometric indices and the mineralization level of humerus, femur and tibia in Leghorn (H-22), Sussex (S-66) and Rhode Island Red (R-11) hens at different age (weeks 6, 16, 45 and 64), as well as some blood parameters. The material for the experiment was one-day old chicks of breeds: Leghorn (H-22), Sussex (S-66) and Rhode Island Red - RIR (R-11), which were separated into three groups. At 6, 16, 45 and 64 weeks of the study, 10 birds selected from each group were weighed, slaughtered, and their right femurs, tibiae and humeri were dissected. After removing soft tissues, the bones were weighed and measured for length, diameter, and the Seedor index (SI) was calculated. The bones were analysed for the content of calcium (Ca), phosphorus (P) and crude ash (CA). At 64 weeks, blood was collected from the hens and analysed for the concentration of $\mathrm{Ca}, \mathrm{P}$, pyridinoline and deoxypyridinoline. The study showed that hen breed had an effect mostly on morphometric indices of the bones such as bone weight and diameter, and the Seedor index (SI), while the age of birds had an effect on the bone mineralization level up to 45 weeks of age. The bone mineralization did not decrease in the studied breeds of hens at the end of the laying period. It was also found that heavier birds (RIR) had greater diameter bones and a higher SI, but the content of ash and minerals in the bones of that breed was generally similar to the Leghorn and Sussex hens. RIR hens exhibited higher plasma phosphorus concentration compared to Sussex hens. This may suggest that RIR birds have a slightly stronger bone system compared to Leghorn and Sussex hens.
\end{abstract}

Key words: bones, morphometric indices, mineralization level, hen breed

The osseous system is both a support for soft tissues of an organism and a protection of key organs against injuries. It also plays a passive role in motion by transmitting the force of muscles, allowing the movements to be made. In addition, the system is a basic reservoir of important elements: calcium, phosphorus and magnesium for

\footnotetext{
*Work financed from statutory activity, project no. 01-12-04-11.
} 
the whole organism. Many changes take place in the bone tissue during the life, including osteogenesis dominating in a young organism and resorption (osteolysis) prevailing in older birds (Whitehead, 2004).

The bones are composed of live osseous tissue cells: osteocytes responsible for bone nutrition, osteoclasts that resorb old bone tissue and osteoblasts that lay down new bone tissue (produce the extracellular matrix).

Thanks to the activity of these cells, the bones undergo a constant rebuilding, allowing growth, reconstruction after damage and adaptation of the bones' shape to the loads acting on them (Rath et al., 2000; Whitehead, 2004; Jiang et al., 2013).

A huge problem in contemporary aviculture of layer hens is the welfare related to the bone damage which causes pain, increased mortality rate and economic losses (Heerkens et al., 2016; Candelotto et al., 2017; Świątkiewicz et al., 2018). The bone damage negatively affects also the birds' mobility and productivity, feed conversion and quality of eggs (Nasr et al., 2014; Heerkens et al., 2016; Casey-Trott et al., 2017 b). Intensive housing systems limiting the chickens' movements lead to the loss of osseous mass and increase the bone brittleness (osteoporosis) and cage layer fatigue (Rodríguez-Navarro et al., 2018). Lay et al. (2011) write that the mortality rate due to osteoporosis is $20-35 \%$ of total deaths. Onbaşilar et al. (2016) claim that $29 \%$ of end-of-lay caged hens had one or more broken bones during their lifetimes, and the total mortality rate caused by bone weakening was $13 \%$. There is also information in the literature on the subject about the high frequency of bone damage in chickens kept in alternative systems (Rodenburg et al., 2008; Käppeli et al., 2011; Wilkins et al., 2011; Heerkens et al., 2016). Although these alternative housing systems allow for increased mobility, which generally stimulates stronger bones (Casey-Trott et al., 2017 a, b; Rodriguez-Navarro et al., 2018), the bone fractures occur rather frequently as a result of hitting the hennery equipment (nests, feeders, drinking bowls) or falling while moving between perches or the levels in the building, and bone damage or deformation caused by an excessive load while sitting on the perch (Pickel et al., 2011; Stratmann et al., 2015; Heerkens et al., 2016). Kolakshyapati et al. (2019) showed that outdoor access did not have a positive effect on bone quality in Lohmann Brown hens.

In Poland, generally native and locally adapted breeds of hens are recommenced for alternative housing, as they are adapted to using the pasture and are less susceptible to unfavourable weather. These breeds are used for organic systems (SosnówkaCzajka et al., 2017) and for production of capons (Calik et al., 2017) and poulards (Obrzut et al., 2018; Krawczyk et al., 2019), high-quality, exclusive niche products (Kuźniacka et al., 2017). Hence, there is a need for studies on the bone quality in native and locally adapted breeds of hens, not only because of animal welfare but also because of the food safety (bone fragments in meat) and economic losses.

In hens, bone tissue is divided into structural (cortical and spongy) and medullary, which acts as a labile source of calcium for eggshell formation (Neijat et al., 2019). The medullary bone is a weaker form of bone tissue and it is found mainly in leg bones (Whitehead and Fleming, 2000; Neijat et al., 2019). In turn, the humerus is pneumatized as a genetic adaptation to flight. Because these bones also differ in the degree of mineralization (Applegate and Lilburn, 2002; Van Wyhe et al., 2012), 
the mechanical load acting on them, and the muscle attachment (Regmi et al., 2017), most studies concentrate on long bones (tibia, femur and humerus) as representative for skeletal health (Jendral et al., 2008; Van Wyhe et al., 2012; Souza et al., 2017).

Van Wyhe et al. (2012) and Ogunwole et al. (2018) write that a healthy skeleton is characterized by the bone mineralization which is strongly correlated with the bone structural strength. Rath et al. (2000) indicate the connection between the bone strength and the bone growth and mass. According to Almeida Paz and Bruno (2006), one of the most important bone quality parameters is mineral density which can be determined by measuring the bone breaking strength or the Seedor index (bone weight to length ratio). The authors state that the skeleton quality depends on many factors, such as age, sex, diet or the egg production.

Many studies also indicate the differences in skeleton quality depending on the breed of the birds. Damaziak et al. (2014) observed that the femurs of fast-growing BUT Big 6 turkeys were significantly thicker and longer compared to those of slowgrowing hybrids of local turkey breeds raised in Poland. Femur fracture resistance was dependent on turkey breed. Onbaşilar et al. (2016) demonstrated differences in femur weight and diameter in Lohmann Brown Classic and Lohmann LSL Classic hens. Mabelebele et al. (2017), who compared femoral and tibial bones from Ross 308 broilers and native Venda hens, noted differences in most of the morphometric parameters and in the crude ash content. Likewise, Regmi et al. (2016) found that the genetic background of Hy-Line Brown and Hy-Line Silver Brown hens had an effect on bone properties. In turn, Tomaszewska et al. (2017) observed tibia and femur measurements to differ between Polbar and Greenleg Partridge cockerels.

Age of birds is another factor influencing bone tissue, mineralization level, and the quantity and quality of collagen fibres (Regmi et al., 2017). During the growth and sexual maturation of hens, bone length and thickness rapidly increase. CaseyTrott et al. (2017 b) state that the onset of osteoporosis may begin between 16 and 31 weeks of age when the amount of spongy bone volume declines by approximately $50 \%$ in favour of medullary bone production. In hens aged over 40 weeks, bone resorption dominates over bone formation, which weakens skeleton quality (Jiang et al., 2019), especially towards the end of the egg production period (Świątkiewicz et al., 2018).

Although various poultry species have been extensively studied for the effect of bird breed on bone development and quality, no information characterizing the bones of locally adapted hens raised in Poland was found. Therefore, this study was aimed to compare morphometric indices and the mineralization level of humeri, femurs and tibiae in Leghorn (H-22), Sussex (S-66) and Rhode Island Red (R-11) hens at different age (weeks 6, 16, 45 and 64), as well as some blood parameters.

\section{Material and methods}

\section{Experimental site}

The experiment was carried out at the poultry farm of the National Research Institute of Animal Production (IZ PIB) in Aleksandrowice, Poland. 


\section{Birds and experimental design}

The material for the experiment was 168 one-day-old chicks included in the genetic resources conservation programme. Chicks were obtained from the Experimental Station of the National Research Institute of Animal Production in Chorzelów (ZD IZ PIB Chorzelów Sp. z o.o.). On the first day of life, chicks were weighed, marked and divided into three groups, depending on breed: Leghorn - H-22 (white-feathered hens) - group I, Sussex - S-66 (white with black-lined cape, flight, sickle and rectrix feathers) - group II, and Rhode Island Red (RIR) - R-11 (dark brown and mahogany feathers) - group III. Each group consisted of 4 subgroups. In subgroups the birds were kept on litter, 9 birds $/ \mathrm{m}^{2}$ (14 birds in subgroups) to the 64th week of life. They were fed $\mathrm{ad}$ libitum with standard feed mixes based on the concentrate dedicated to layer hens (Table 1). The birds had an unrestricted access to drinking bowls throughout the experiment. The temperature was kept at $33-31^{\circ} \mathrm{C}$ in initial days, and then was gradually reduced to $16^{\circ} \mathrm{C}$ in the 11 th week. The relative humidity was kept at $65 \%$. The lighting programme during the laying period included 16 hours of light and 8 hours of darkness.

Table 1. Ingredient composition (\%) and nutritive value of diets

\begin{tabular}{|c|c|c|c|}
\hline \multirow{2}{*}{ Item } & \multicolumn{3}{|c|}{ Laying periods (weeks of age) } \\
\hline & $1-7$ & $8-16$ & $>17$ \\
\hline Wheat & 62.65 & 63.18 & - \\
\hline Corn & 10.00 & - & - \\
\hline Ground maize & - & - & 58.1 \\
\hline Barley & - & 12.00 & - \\
\hline Wheat bran & - & 10.00 & 4.00 \\
\hline Soybean meal & 23.00 & 11.00 & 15.00 \\
\hline Rapeseed cake & - & - & 3.00 \\
\hline DDGS corn & - & - & 7.00 \\
\hline Dried alfalfa & - & - & 2.00 \\
\hline Mineral-vitamin premix ${ }^{1,2}$ & $0.50^{1}$ & $0.50^{1}$ & $1.00^{2}$ \\
\hline Limestone & 1.30 & 1.55 & 8.60 \\
\hline Monocalcium phosphate & 1.80 & 1.15 & 1.00 \\
\hline $\mathrm{NaCl}$ & 0.35 & 0.35 & 0.25 \\
\hline DL-Methionine & 0.22 & 0.13 & 0.05 \\
\hline Lysine & 0.18 & 0.14 & - \\
\hline \multicolumn{4}{|c|}{ Nutritive value per kg } \\
\hline Crude protein $(\%)$ & 20.0 & 15.0 & 15.8 \\
\hline Metabolisable energy (MJ) & 11.7 & 11.3 & 11.2 \\
\hline Lysine (g) & 10.0 & 7.0 & 7.0 \\
\hline Methionine (g) & 3.10 & 2.8 & 3.3 \\
\hline Calcium (g) & 9.5 & 8.5 & 34.1 \\
\hline Phosphorus (g) & 4.5 & 4.2 & 3.4 \\
\hline
\end{tabular}

${ }^{1}$ Provided per kilogram of diet: vit. A $10000 \mathrm{IU}$; vit. D $250 \mathrm{IU}$; vit. E 35 IU; vit. K 3 mg; vit. B 2 mg; vit. $\mathrm{B}_{2} 6 \mathrm{mg}$; vit. B $4 \mathrm{mg}$; vit. $\mathrm{B}_{12} 45 \mathrm{mcg}$; niacin $6 \mathrm{mg}$; D-Ca-pantothenate $150 \mathrm{mg}$; folic acid $1 \mathrm{mg}$; biotin $15 \mathrm{mcg}$; choline chloride $224 \mathrm{mg}$; Cu 15 mg; Fe 60 mg; I 1.5 mg; Mn 80 mg; Zn 90 mg; Se 0.25 mg; coccidiostats.

${ }^{2}$ Provided per kilogram of diet: vit. A $10000 \mathrm{IU}$; vit. $\mathrm{D}_{3} 2500 \mathrm{IU}$; vit. E $25 \mathrm{IU}$; Mn (manganese oxide) $85 \mathrm{mg}$; Mn (dimangan trihydroxychloride) $15 \mathrm{mg}$; Cu 15 mg; Fe $70 \mathrm{mg}$; Zn 80 mg; I $1.5 \mathrm{mg}$; Se $0.2 \mathrm{mg}$; Ca min. $0.84 \mathrm{~g}$; $\mathrm{Na} 1.57 \mathrm{~g}$; crude protein $1.45 \mathrm{~g}$; crude fiber $0.002 \mathrm{~g}$; ash 6.60 ; crude fat $0.072 \mathrm{~g}$; lysine $0.3 \mathrm{~g}$; methionine $1.5 \mathrm{~g} ; \mathrm{ME} 19.08 \mathrm{kcal}$. 
The experiment was conducted with approval (no. 58/2017) of the I Local Ethics Committee for Animal Experimentation in Kraków.

\section{Data, sample collection and laboratory analyses}

During the experiment 10 birds per group were randomly selected in the 6th, 16 th, 45th and 64th weeks. Selected birds were weighed and slaughtered, and their right femoral, tibial and humeral bones were dissected. The soft tissue was removed, the bones were weighed and the length and diameter of the bones (at the longest and at the narrowest point, respectively) were measured using an electronic slide calliper. Bone diameter was measured at the middle of the shaft (horizontal plane). The Seedor index was calculated using the formula SI = bone weight $(\mathrm{mg}) /$ bone length $(\mathrm{mm})$ to indicate the bone density (Souza et al., 2017). Percentage of dissected bones in relation to body weight was also calculated. The dissected bones were analysed for the content of calcium $(\mathrm{Ca})$, phosphorus $(\mathrm{P})$ and crude ash $(\mathrm{CA})$. Bones were incinerated in a muffle furnace in three stages: at $600^{\circ} \mathrm{C}$ for $21 \mathrm{~h}$, after which the temperature was increased over $2 \mathrm{~h}$ to $850^{\circ} \mathrm{C}$ and the samples were kept at this temperature for $1 \mathrm{~h}$. The obtained ash was homogenized. Weighed amount of ash was diluted at room temperature in $100 \mathrm{ml}$ flasks in $0.6 \mathrm{~mol} / 1 \mathrm{HCl}$. The obtained solution was analysed for the content of $\mathrm{Ca}$ by atomic absorption spectrometry and for $\mathrm{P}$ by the spectrophotometric method (700 nm wavelength). Crude ash was analysed according to the method of Coutand et al. (2008).

Blood was collected from 10 birds per group to determine: pyridinoline, deoxypyridinoline, calcium (Ca) and phosphorus $(\mathrm{P})$ in the 64 th week of age (towards the end of the egg production period). The blood was collected in the morning hours from the wing vein using a vacuum blood taking kit. After collection, the blood was centrifuged (MPW-52 centrifuge) and the plasma separated by centrifugation was transferred to Eppendorf tubes. The analysis of $\mathrm{Ca}$ and $\mathrm{P}$ in the birds' blood was made using a Mindray BS-120 biochemic analyser and reagents and methodology from Alpha Diagnostics. Pyridinoline and deoxypyridinoline were determined by the enzyme immunoassay (EIA) on a Mindray MR-96 A ELISA reader using Chicken Pyridinoline ELISA Kit (Cat.No E0246Ch) and Chicken Deoxypyridinoline Crosslinks ELISA Kit (Cat.No E0248Ch) by Bioassay Technology Laboratory (BT Lab, Shanghai, China).

\section{Statistical analyses}

The statistical analyses were made using the Statistica 12 software. The results for body weight, bone morphometric indices and blood parameters were statistically analysed by one-way ANOVA. Two-way ANOVA was used to determine differences between hen breeds and hen ages, as well as their interactions with the level of crude ash, calcium, phosphorus, and the Ca:P ratio in humeri, femurs and tibiae. Significant differences for the means between the experimental groups were determined with Duncan's test. Effects were considered significant at a probability of $\mathrm{P}<0.05$ and $\mathrm{P}<0.01$. 


\section{Results}

Table 2 presents body weight and the morphometric indices of bones of the three hen breeds at 6 weeks of age. The differences in the tibia bone diameter were noticed between the Leghorn and the Sussex, and the RIR at $\mathrm{P}<0.05$. In the 16th week of age (Table 3), the RIR hens had the greatest body mass, compared to the Leghorn at $\mathrm{P}<0.05$ and the Sussex at $\mathrm{P}<0.01$. The difference in the humerus bone weight was also noticed between Leghorn and Sussex hens $\mathrm{P}<0.05$ ). The difference in relative bone weight of humerus was noticed between Sussex and RIR hens at $\mathrm{P}<0.05$. The Sussex hens had the widest humerus bone of all three breeds at $\mathrm{P}<0.05$. At 16 weeks, humerus Seedor indexes in Leghorn were significantly greater than in Sussex $(\mathrm{P}<0.05$; Table 3). As regards the femur, Sussex hens were characterized by lower femur weight in relation to the other two breeds $(\mathrm{P}<0.05)$, higher femur percentage compared to RIR hens $(\mathrm{P}<0.05)$, and lowest Seedor index compared to Leghorn and RIR hens $(\mathrm{P}<0.05)$. The greatest tibia bone weight was in RIR hens, the least in Sussex hens, at $\mathrm{P}<0.01$. The difference was also noticed in relative bone weight of tibia, its diameter and the Seedor index between Sussex and RIR hens at $\mathrm{P}<0.05$. Table 4 presents body weight and the morphometric indices of bones of the three hen breeds at 45 weeks of age. The RIR hens still had the greatest body weight when compared to the other breeds at $\mathrm{P}<0.05$. The differences in the humerus bone were noticed only in terms of its diameter and the Seedor index between Sussex and RIR hens at $\mathrm{P}<0.05$. between the Leghorn and the RIR $(\mathrm{P}<0.05)$. Femur and tibia bone weight was highest in RIR hens, at $\mathrm{P}<0.05$ and $\mathrm{P}<0.01$. The differences were also noticed in the femur bone diameter and Seedor index between the Leghorn and the RIR hens at $\mathrm{P}<0.05$, and in tibia bone between the RIR and the Leghorn and Sussex hens, at $\mathrm{P}<0.01$ and $\mathrm{P}<0.05$, respectively. In the 64th week of the experiment, the differences were noticed in body weight between the Leghorn and Sussex and RIR hens at $\mathrm{P}<0.01$ (Table 5). The humerus bones from the RIR hens were heavier and longer than those of the Leghorn hens at $\mathrm{P}<0.01$ and $\mathrm{P}<0.05$ and of the Sussex hens at $\mathrm{P}<0.05$ and $\mathrm{P}<0.01$. The differences in diameter and the Seedor index were also noticed between the RIR and the Leghorn, at $\mathrm{P}<0.05$ and $\mathrm{P}<0.01$, respectively. The Leghorn had the lightest femur bone compared with the Sussex and the RIR at $\mathrm{P}<0.01$, and the difference in the percent share of the femur in relation to the body weight was noticed between the Leghorn and the RIR at $\mathrm{P}<0.01$. The RIR had the greatest femur Seedor index, and the Leghorns had the least at $\mathrm{P}<0.01$. In the last week of the experiment, the tibia bones from the RIR had greater morphometric indices than the tibia bones from the Leghorn and the Sussex, at $\mathrm{P}<0.05$ and $\mathrm{P}<0.01$.

Table 6 presents $\mathrm{CA}, \mathrm{Ca}, \mathrm{P}$ levels and $\mathrm{Ca}$ to $\mathrm{P}$ ratio in the humerus bones as affected by breed and age and their interactions. A difference in the crude ash and $\mathrm{P}$ levels were noticed in the humerus bones of the Leghorn and the Sussex at $\mathrm{P}<0.05$. The lowest $\mathrm{Ca}$ to $\mathrm{P}$ ratio was characteristic of the humerus of Sussex hens compared to Leghorn and RIR hens $(\mathrm{P}<0.05)$. The level of $\mathrm{CA}, \mathrm{Ca}, \mathrm{P}$ and $\mathrm{Ca}$ to $\mathrm{P}$ ratio in humerus bones of hens increased up to the 45 th week of rearing, at $\mathrm{P}<0.01$. 
Table 2. Body weight and bone morphometric parameters of hens at 6 weeks of age ${ }^{1}$

\begin{tabular}{|c|c|c|c|c|}
\hline \multirow[b]{2}{*}{ Item } & \multicolumn{3}{|c|}{ Group } & \multirow{2}{*}{$\begin{array}{c}\text { Pooled } \\
\text { SEM }\end{array}$} \\
\hline & $\begin{array}{c}\text { Leghorn } \\
\text { H-22 }\end{array}$ & $\begin{array}{c}\text { Sussex } \\
\text { S-66 }\end{array}$ & $\begin{array}{l}\text { RIR } \\
\text { R-11 }\end{array}$ & \\
\hline Body weight (g) & 435.20 & 457.68 & 436.98 & 9.82 \\
\hline \multicolumn{5}{|c|}{ Humerus } \\
\hline Bone weight (g) & 2.33 & 2.51 & 2.17 & 0.08 \\
\hline Relative bone weight (\%) & 0.533 & 0.549 & 0.498 & 0.013 \\
\hline Length (mm) & 54.85 & 54.80 & 53.79 & 0.46 \\
\hline Diameter (mm) & 4.13 & 3.98 & 3.91 & 0.05 \\
\hline $\mathrm{SI}(\mathrm{mg} / \mathrm{mm})$ & 42.48 & 45.80 & 40.34 & 1.00 \\
\hline \multicolumn{5}{|c|}{ Femur } \\
\hline Bone weight (g) & 2.89 & 3.12 & 2.77 & 0.09 \\
\hline Relative bone weight (\%) & 0.66 & 0.68 & 0.65 & 0.01 \\
\hline Length (mm) & 55.38 & 58.45 & 56.28 & 0.88 \\
\hline Diameter (mm) & 5.06 & 5.09 & 5.03 & 0.07 \\
\hline $\mathrm{SI}(\mathrm{mg} / \mathrm{mm})$ & 52.19 & 53.38 & 49.22 & 1.00 \\
\hline \multicolumn{5}{|c|}{ Tibia } \\
\hline Bone weight (g) & 3.86 & 3.93 & 3.80 & 0.11 \\
\hline Relative bone weight (\%) & 0.886 & 0.854 & 0.871 & 0.013 \\
\hline Length (mm) & 80.06 & 79.57 & 77.83 & 0.71 \\
\hline Diameter (mm) & $4.07 \mathrm{a}$ & $4.08 \mathrm{a}$ & $4.55 \mathrm{~b}$ & 0.10 \\
\hline $\mathrm{SI}$ (mg/mm) & 48.21 & 49.39 & 48.82 & 1.00 \\
\hline
\end{tabular}

Pooled SEM - pooled standard error of mean.

SI - Seedor index.

$\mathrm{a}, \mathrm{b}-$ values in rows with different letters differ significantly $(\mathrm{P}<0.05)$.

${ }^{1}$ Data are means of 10 replicates.

Table 3. Body weight and bone morphometric parameters of hens at 16 weeks of age ${ }^{1}$

\begin{tabular}{|c|c|c|c|c|}
\hline \multirow[b]{2}{*}{ Item } & \multicolumn{3}{|c|}{ Group } & \multirow{2}{*}{$\begin{array}{c}\text { Pooled } \\
\text { SEM }\end{array}$} \\
\hline & $\begin{array}{c}\text { Leghorn } \\
\text { H-22 }\end{array}$ & $\begin{array}{c}\text { Sussex } \\
\text { S-66 }\end{array}$ & $\begin{array}{l}\text { RIR } \\
\text { R-11 }\end{array}$ & \\
\hline 1 & 2 & 3 & 4 & 5 \\
\hline Body weight (g) & $1487.5 \mathrm{a}$ & $1200.0 \mathrm{bAa}$ & 1737.5 Bb & 78.80 \\
\hline \multicolumn{5}{|c|}{ Humerus } \\
\hline Bone weight (g) & $5.082 \mathrm{a}$ & $4.321 \mathrm{~b}$ & 4.993 & 0.15 \\
\hline Relative bone weight (\%) & 0.345 & $0.361 \mathrm{a}$ & $0.292 \mathrm{~b}$ & 0.013 \\
\hline Length (mm) & 78.27 & 78.20 & 79.86 & 0.60 \\
\hline Diameter (mm) & $6.62 \mathrm{a}$ & $5.92 \mathrm{~b}$ & $6.59 \mathrm{a}$ & 0.13 \\
\hline $\mathrm{SI}(\mathrm{mg} / \mathrm{mm})$ & $64.93 \mathrm{a}$ & $55.26 \mathrm{~b}$ & 62.52 & 2.00 \\
\hline
\end{tabular}


Table 2 - contd.

\begin{tabular}{|c|c|c|c|c|}
\hline 1 & 2 & 3 & 4 & 5 \\
\hline \multicolumn{5}{|c|}{ Femur } \\
\hline Bone weight (g) & $8.43 \mathrm{a}$ & $7.44 \mathrm{~b}$ & $8.60 \mathrm{a}$ & 0.22 \\
\hline Relative bone weight (\%) & 0.57 & $0.62 \mathrm{a}$ & $0.49 \mathrm{~b}$ & 0.02 \\
\hline Length (mm) & 86.84 & 86.94 & 88.02 & 0.65 \\
\hline Diameter (mm) & 8.06 & 7.01 & 7.40 & 0.21 \\
\hline SI (mg/mm) & $97.08 \mathrm{a}$ & $85.58 \mathrm{~b}$ & $97.71 \mathrm{a}$ & 3.00 \\
\hline \multicolumn{5}{|c|}{ Tibia } \\
\hline Bone weight (g) & $10.36 \mathrm{~b}$ & $9.08 \mathrm{Aa}$ & $10.83 \mathrm{~B}$ & 0.27 \\
\hline Relative bone weight (\%) & 0.700 & $0.758 \mathrm{a}$ & $0.628 \mathrm{~b}$ & 0.022 \\
\hline Length (mm) & 125.30 & 124.13 & 125.64 & 0.73 \\
\hline Diameter (mm) & 6.43 & $5.99 \mathrm{a}$ & $6.65 \mathrm{~b}$ & 0.11 \\
\hline SI (mg/mm) & 82.68 & $73.15 \mathrm{a}$ & $86.20 \mathrm{~b}$ & 2.00 \\
\hline
\end{tabular}

Pooled SEM - pooled standard error of mean.

$\mathrm{SI}$ - Seedor index.

$\mathrm{a}, \mathrm{b}$ - values in rows with different letters differ significantly $(\mathrm{P}<0.05$.

$\mathrm{A}, \mathrm{B}-$ values in rows with different letters differ highly significantly $(\mathrm{P}<0.01)$.

${ }^{1}$ Data are means of 10 replicates.

Table 4. Body weight and bone morphometric parameters of hens at 45 weeks of age ${ }^{1}$

\begin{tabular}{|c|c|c|c|c|}
\hline \multirow{2}{*}{ Item } & \multicolumn{3}{|c|}{ Group } & \multirow{2}{*}{$\begin{array}{c}\text { Pooled } \\
\text { SEM }\end{array}$} \\
\hline & $\begin{array}{c}\text { Leghorn } \\
\text { H-22 }\end{array}$ & $\begin{array}{c}\text { Sussex } \\
\text { S-66 }\end{array}$ & $\begin{array}{l}\text { RIR } \\
\text { R-11 }\end{array}$ & \\
\hline 1 & 2 & 3 & 4 & 5 \\
\hline Body weight (g) & $2125.0 \mathrm{a}$ & $2242.5 \mathrm{a}$ & $2585.0 \mathrm{~b}$ & 80.61 \\
\hline \multicolumn{5}{|c|}{ Humerus } \\
\hline Bone weight (g) & 5.32 & 5.30 & 5.75 & 0.19 \\
\hline Relative bone weight (\%) & 0.25 & 0.24 & 0.22 & 0.01 \\
\hline Length (mm) & 73.01 & 78.80 & 81.62 & 2.37 \\
\hline Diameter (mm) & $6.01 \mathrm{a}$ & 6.49 & $6.65 \mathrm{~b}$ & 0.11 \\
\hline $\mathrm{SI}(\mathrm{mg} / \mathrm{mm})$ & 72.87 & 67.26 & 70.45 & 3.00 \\
\hline \multicolumn{5}{|l|}{ Femur } \\
\hline Bone weight (g) & $9.22 \mathrm{a}$ & $9.96 \mathrm{a}$ & $12.23 \mathrm{~b}$ & 0.51 \\
\hline Relative bone weight (\%) & 0.44 & 0.44 & 0.49 & 0.02 \\
\hline Length (mm) & 87.57 & 86.49 & 91.55 & 1.03 \\
\hline Diameter (mm) & $7.29 \mathrm{a}$ & 7.48 & $8.22 \mathrm{~b}$ & 0.17 \\
\hline $\mathrm{SI}(\mathrm{mg} / \mathrm{mm})$ & $105.29 \mathrm{a}$ & 115.16 & $133.59 \mathrm{~b}$ & 5.00 \\
\hline
\end{tabular}


Table 4 - contd.

\begin{tabular}{lccccc}
\hline \multicolumn{1}{c|}{1} & 2 & 3 & 4 & 5 \\
\hline \multicolumn{7}{c}{ Tibia } \\
Bone weight (g) & $10.47 \mathrm{~A}$ & $11.54 \mathrm{~A}$ & $14.66 \mathrm{~B}$ & 0.63 \\
Relative bone weight (\%) & 0.501 & 0.517 & 0.571 & 0.02 \\
Length (mm) & 125.21 & 125.54 & 127.55 & 1.06 \\
Diameter (mm) & $5.79 \mathrm{~A}$ & $6.12 \mathrm{~A}$ & $6.93 \mathrm{~B}$ & 0.16 \\
SI (mg/mm) & $83.62 \mathrm{a}$ & $91.92 \mathrm{a}$ & $114.94 \mathrm{~b}$ & 10.0 \\
\hline
\end{tabular}

Pooled SEM - pooled standard error of mean.

SI - Seedor index.

$\mathrm{a}, \mathrm{b}-$ values in rows with different letters differ significantly $(\mathrm{P}<0.05)$.

$\mathrm{A}, \mathrm{B}-$ values in rows with different letters differ highly significantly $(\mathrm{P}<0.01)$.

${ }^{1}$ Data are means of 10 replicates.

Table 5. Body weight and bone morphometric parameters of hens at 64 weeks of age ${ }^{1}$

\begin{tabular}{|c|c|c|c|c|}
\hline \multirow[b]{2}{*}{ Item } & \multicolumn{3}{|c|}{ Group } & \multirow{2}{*}{$\begin{array}{c}\text { Pooled } \\
\text { SEM }\end{array}$} \\
\hline & $\begin{array}{c}\text { Leghorn } \\
\text { H-22 }\end{array}$ & $\begin{array}{c}\text { Sussex } \\
\text { S-66 }\end{array}$ & $\begin{array}{l}\text { RIR } \\
\text { R-11 }\end{array}$ & \\
\hline Body weight (g) & $2201.67 \mathrm{~A}$ & $2360,00 \mathrm{~B}$ & 2397,14 B & 24.94 \\
\hline \multicolumn{5}{|c|}{ Humerus } \\
\hline Bone weight (g) & $4.67 \mathrm{~A}$ & $5.14 \mathrm{a}$ & $5.88 \mathrm{Bb}$ & 0.16 \\
\hline Relative bone weight (\%) & 0.21 & 0.22 & 0.24 & 0.004 \\
\hline Length (mm) & $79.91 \mathrm{a}$ & $79.03 \mathrm{~A}$ & $82.42 \mathrm{Bb}$ & 0.50 \\
\hline Diameter (mm) & $6.32 \mathrm{a}$ & 6.38 & $6.65 \mathrm{~b}$ & 0.06 \\
\hline $\mathrm{SI}(\mathrm{mg} / \mathrm{mm})$ & $58.75 \mathrm{~A}$ & 65.04 & $71.33 \mathrm{~B}$ & 1.78 \\
\hline \multicolumn{5}{|c|}{ Femur } \\
\hline Bone weight (g) & $8.94 \mathrm{~A}$ & $10.80 \mathrm{~B}$ & $11.58 \mathrm{~B}$ & 0.34 \\
\hline Relative bone weight (\%) & $0.41 \mathrm{~A}$ & 0.46 & $0.48 \mathrm{~B}$ & 0.01 \\
\hline Length (mm) & 85.27 & 89.32 & 88.14 & 1.29 \\
\hline Diameter (mm) & 7.67 & 7.88 & 7.92 & 0.14 \\
\hline $\mathrm{SI}(\mathrm{mg} / \mathrm{mm})$ & $104.85 \mathrm{~A}$ & $120.84 \mathrm{Ba}$ & $131.65 \mathrm{Bb}$ & 3.10 \\
\hline \multicolumn{5}{|c|}{ Tibia } \\
\hline Bone weight (g) & $10.31 \mathrm{~A}$ & $12.23 \mathrm{a}$ & $13.96 \mathrm{Bb}$ & 0.43 \\
\hline Relative bone weight (\%) & $0.47 \mathrm{~A}$ & $0.52 \mathrm{a}$ & $0.59 \mathrm{Bb}$ & 0.02 \\
\hline Length (mm) & 123.37 & 127.06 & 127.80 & 0.98 \\
\hline Diameter (mm) & $6.17 \mathrm{~A}$ & $6.36 \mathrm{~A}$ & $7.34 \mathrm{~B}$ & 0.17 \\
\hline $\mathrm{SI}(\mathrm{mg} / \mathrm{mm})$ & $84.12 \mathrm{Aa}$ & $96.22 \mathrm{Ab}$ & $109.82 \mathrm{~B}$ & 2.92 \\
\hline
\end{tabular}

Pooled SEM - pooled standard error of mean.

SI - Seedor index.

$\mathrm{a}, \mathrm{b}-$ values in rows with different letters differ significantly $(\mathrm{P}<0.05)$.

$\mathrm{A}, \mathrm{B}-$ values in rows with different letters differ highly significantly $(\mathrm{P}<0.01)$.

${ }^{1}$ Data are means of 10 replicates. 
Table 6. Crude ash (CA), calcium $(\mathrm{Ca})$ and phosphorus $(\mathrm{P})$ content and $\mathrm{Ca}$ to $\mathrm{P}$ ratio in humerus bones as affected by breed and age and their interactions ${ }^{1}$

\begin{tabular}{|c|c|c|c|c|c|c|}
\hline \multicolumn{3}{|c|}{ Item } & $\mathrm{CA}(\%)$ & $\mathrm{Ca}(\mathrm{g} / \mathrm{kg})$ & $\mathrm{P}(\mathrm{g} / \mathrm{kg})$ & $\mathrm{Ca}: \mathrm{P}$ \\
\hline \multirow{3}{*}{\multicolumn{2}{|c|}{ Breed }} & Leghorn H-22 & $34.91 \mathrm{a}$ & 136.36 & $62.09 \mathrm{a}$ & $2.17 \mathrm{a}$ \\
\hline & & Sussex S-66 & $37.76 \mathrm{~b}$ & 145.66 & $67.18 \mathrm{~b}$ & $2.14 \mathrm{~b}$ \\
\hline & & RIR R-11 & 37.01 & 144.58 & 65.58 & $2.18 \mathrm{a}$ \\
\hline \multirow{4}{*}{\multicolumn{2}{|c|}{ Age (weeks) }} & 6 & $19.59 \mathrm{~A}$ & $72.16 \mathrm{~A}$ & $35.30 \mathrm{~A}$ & $2.05 \mathrm{~A}$ \\
\hline & & 16 & $36.68 \mathrm{~B}$ & $139.07 \mathrm{~B}$ & $66.36 \mathrm{~B}$ & $2.10 \mathrm{~B}$ \\
\hline & & 45 & $44,15 \mathrm{C}$ & $174.23 \mathrm{C}$ & $77.42 \mathrm{C}$ & $2.25 \mathrm{C}$ \\
\hline & & 64 & $45.81 \mathrm{C}$ & $183.33 \mathrm{C}$ & $80.71 \mathrm{C}$ & $2.27 \mathrm{C}$ \\
\hline \multirow{12}{*}{ 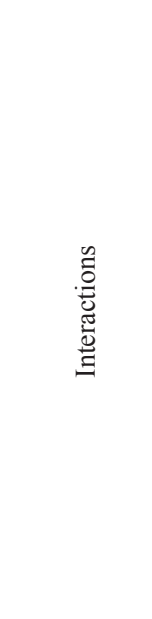 } & \multirow{4}{*}{$\begin{array}{l}\text { Leghorn } \\
\mathrm{H}-22\end{array}$} & 6 & 18.85 & 69.87 & 34.10 & 2.05 \\
\hline & & 16 & 34.25 & 130.17 & 61.83 & 2.11 \\
\hline & & 45 & 43.78 & 173.40 & 77.07 & 2.25 \\
\hline & & 64 & 42.78 & 172.00 & 75.37 & 2.28 \\
\hline & \multirow{4}{*}{$\begin{array}{l}\text { Sussex } \\
\text { S-66 }\end{array}$} & 6 & 19.65 & 72.03 & 35.50 & 2.03 \\
\hline & & 16 & 39.23 & 146.43 & 71.13 & 2.05 \\
\hline & & 45 & 43.57 & 170.50 & 76.50 & 2.23 \\
\hline & & 64 & 48.57 & 193.67 & 85.57 & 2.26 \\
\hline & \multirow{4}{*}{$\begin{array}{l}\text { RIR } \\
\text { R-11 }\end{array}$} & 6 & 20.27 & 74.57 & 36.30 & 2.06 \\
\hline & & 16 & 36.55 & 140.60 & 66.10 & 2.13 \\
\hline & & 45 & 45.10 & 178.80 & 78.70 & 2.27 \\
\hline & & 64 & 46.10 & 184.33 & 81.20 & 2.27 \\
\hline \multicolumn{3}{|l|}{ Pooled SEM } & 1.81 & 7.59 & 3.13 & 0.02 \\
\hline \multicolumn{3}{|l|}{ Breed (A) } & $<0.05$ & NS & $<0.05$ & $<0.05$ \\
\hline \multicolumn{3}{|l|}{ Age (B) } & $<0.01$ & $<0.01$ & $<0.01$ & $<0.01$ \\
\hline \multicolumn{3}{|l|}{$A \times B$} & NS & NS & NS & NS \\
\hline
\end{tabular}

Pooled SEM - pooled standard error of mean.

$\mathrm{a}, \mathrm{b}$ - values in columns with different letters differ significantly $(\mathrm{P}<0.05)$.

A, B - values in columns with different letters differ highly significantly $(\mathrm{P}<0.01)$.

NS - not significant.

${ }^{1}$ Data are means of 10 replicates.

Table 7 presents $\mathrm{CA}, \mathrm{Ca}, \mathrm{P}$ levels and $\mathrm{Ca}$ to $\mathrm{P}$ ratio in the femur bones as affected by breed and age and their interactions. The calcium to phosphorus ratio in the femurs was found to differ between Leghorn and RIR hens $(\mathrm{P}<0.05)$. The age of hens had an effect on the level of parameters analysed in the femurs $(\mathrm{P}<0.01)$. Hen breed had no effect on the level of $\mathrm{CA}, \mathrm{Ca}$ and $\mathrm{P}$, and on the $\mathrm{Ca}: \mathrm{P}$ ratio in tibia (Table 8). In turn, the effect of hen age on the analysed parameters was highly significant $(\mathrm{P}<0.01)$. 
Table 7. Crude ash (CA), calcium (Ca) and phosphorus $(\mathrm{P})$ and $\mathrm{Ca}$ to $\mathrm{P}$ ratio in femur bones as affected by breed and age and their interactions ${ }^{1}$

\begin{tabular}{|c|c|c|c|c|c|c|}
\hline \multicolumn{3}{|c|}{ Item } & Ash (\%) & $\mathrm{Ca}(\mathrm{g} / \mathrm{kg})$ & $\mathrm{P}(\mathrm{g} / \mathrm{kg})$ & $\mathrm{Ca}: \mathrm{P}$ \\
\hline \multirow{3}{*}{\multicolumn{2}{|c|}{ Breed }} & Leghorn H-22 & 27.11 & 104.75 & 48.34 & $2.13 \mathrm{a}$ \\
\hline & & Sussex S-66 & 29.87 & 115.28 & 52.93 & 2.14 \\
\hline & & RIR R-11 & 28.89 & 112.06 & 50.95 & $2.16 \mathrm{~b}$ \\
\hline \multirow{4}{*}{\multicolumn{2}{|c|}{ Age (weeks) }} & 6 & $17.23 \mathrm{~A}$ & $62.59 \mathrm{~A}$ & $31.42 \mathrm{~A}$ & $1.99 \mathrm{~A}$ \\
\hline & & 16 & $21.93 \mathrm{~B}$ & $82.08 \mathrm{~B}$ & $39.83 \mathrm{~B}$ & $2.06 \mathrm{~B}$ \\
\hline & & 45 & $35.99 \mathrm{C}$ & $141.12 \mathrm{C}$ & $62.96 \mathrm{C}$ & $2.24 \mathrm{C}$ \\
\hline & & 64 & $39.35 \mathrm{C}$ & $157.00 \mathrm{D}$ & $68.74 \mathrm{C}$ & $2.28 \mathrm{D}$ \\
\hline \multirow{12}{*}{ 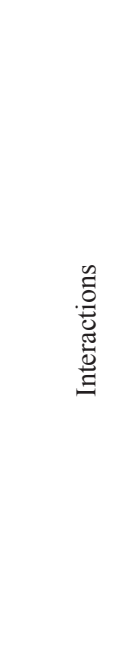 } & \multirow{4}{*}{$\begin{array}{l}\text { Leghorn } \\
\text { H-22 }\end{array}$} & 6 & 17.47 & 63.57 & 31.77 & 2.00 \\
\hline & & 16 & 20.43 & 76.27 & 37.37 & 2.04 \\
\hline & & 45 & 36.59 & 143.83 & 64.40 & 2.23 \\
\hline & & 64 & 33.95 & 136.33 & 59.83 & 2.26 \\
\hline & \multirow{4}{*}{$\begin{array}{l}\text { Sussex } \\
\text { S-66 }\end{array}$} & 6 & 17.27 & 62.87 & 31.70 & 1.98 \\
\hline & & 16 & 23.20 & 86.73 & 42.17 & 2.06 \\
\hline & & 45 & 37.34 & 145.87 & 65.33 & 2.23 \\
\hline & & 64 & 41.66 & 165.67 & 72.50 & 2.29 \\
\hline & \multirow{4}{*}{$\begin{array}{l}\text { RIR } \\
\text { R-11 }\end{array}$} & 6 & 16.93 & 61.33 & 30.80 & 1.99 \\
\hline & & 16 & 22.15 & 83.23 & 39.97 & 2.08 \\
\hline & & 45 & 34.03 & 133.67 & 59.13 & 2.26 \\
\hline & & 64 & 42.44 & 170.00 & 73.90 & 2.30 \\
\hline \multicolumn{3}{|c|}{ Pooled SEM } & 1.69 & 7.13 & 2.84 & 0.02 \\
\hline \multicolumn{3}{|l|}{ Breed (A) } & NS & NS & NS & $<0.05$ \\
\hline \multicolumn{3}{|l|}{ Age (B) } & $<0.01$ & $<0.01$ & $<0.01$ & $<0.01$ \\
\hline \multicolumn{3}{|l|}{$A \times B$} & NS & NS & NS & NS \\
\hline
\end{tabular}

Pooled SEM - pooled standard error of mean.

$\mathrm{a}, \mathrm{b}-$ values in columns with different letters differ significantly $(\mathrm{P}<0.05)$.

A, B - values in columns with different letters differ highly significantly $(\mathrm{P}<0.01)$.

NS - not significant.

${ }^{1}$ Data are means of 10 replicates.

In the 64th week of age the RIR had a higher phosphorus level than the Sussex at $\mathrm{P}<0.01$ (Table 9). 
Table 8. Crude ash (CA), calcium $(\mathrm{Ca})$ and phosphorus $(\mathrm{P})$ and $\mathrm{Ca}$ to $\mathrm{P}$ ratio in tibia bone as affected by breed and age and their interactions ${ }^{1}$

\begin{tabular}{|c|c|c|c|c|c|c|}
\hline \multicolumn{3}{|c|}{ Item } & \multirow{2}{*}{$\begin{array}{c}\text { Ash (\%) } \\
29.50\end{array}$} & \multirow{2}{*}{$\begin{array}{l}\mathrm{Ca}(\mathrm{g} / \mathrm{kg}) \\
114.13\end{array}$} & \multirow{2}{*}{$\frac{\mathrm{P}(\mathrm{g} / \mathrm{kg})}{52.61}$} & \multirow{2}{*}{$\begin{array}{c}\mathrm{Ca}: \mathrm{P} \\
2.14\end{array}$} \\
\hline Breed & & Leghorn H-22 & & & & \\
\hline & & Sussex S-66 & 31.11 & 120.77 & 55.38 & 2.15 \\
\hline & & RIR R-11 & 29.89 & 116.19 & 53.06 & 2.16 \\
\hline \multirow[t]{8}{*}{ Age (weeks) } & & 6 & $17.77 \mathrm{~A}$ & $64.71 \mathrm{~A}$ & $32.14 \mathrm{~A}$ & $2.01 \mathrm{~A}$ \\
\hline & & 16 & $26.36 \mathrm{~B}$ & $99.63 \mathrm{~B}$ & $47.83 \mathrm{~B}$ & $2.08 \mathrm{~B}$ \\
\hline & & 45 & $37.08 \mathrm{C}$ & $146.10 \mathrm{C}$ & $65.26 \mathrm{C}$ & $2.24 \mathrm{C}$ \\
\hline & & 64 & $39.46 \mathrm{C}$ & $157.67 \mathrm{C}$ & $69.50 \mathrm{C}$ & $2.27 \mathrm{D}$ \\
\hline & Leghorn & 6 & 18.29 & 66.73 & 33.10 & 2.02 \\
\hline & & 16 & 24.94 & 93.73 & 45.23 & 2,07 \\
\hline & & 45 & 39.94 & 149.70 & 66.87 & 2.24 \\
\hline & & 64 & 36.83 & 146.33 & 65.23 & 2.24 \\
\hline \multirow{8}{*}{ 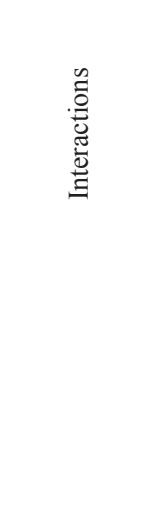 } & Sussex & 6 & 17.44 & 63.60 & 31.63 & 2.01 \\
\hline & S-66 & 16 & 28.10 & 106.67 & 51.20 & 2.09 \\
\hline & & 45 & 38.47 & 150.80 & 67.87 & 2.23 \\
\hline & & 64 & 40.45 & 162.00 & 70.83 & 2.29 \\
\hline & RIR & 6 & 17.58 & 63.80 & 31.70 & 2.01 \\
\hline & R-11 & 16 & 26.04 & 98.50 & 47.07 & 2.09 \\
\hline & & 45 & 34.84 & 137.80 & 61.03 & 2.26 \\
\hline & & 64 & 41.12 & 164.67 & 72.43 & 2.27 \\
\hline Pooled SEM & & & 1.54 & 6.58 & 2.65 & 0.02 \\
\hline Breed (A) & & & NS & NS & NS & NS \\
\hline Age (B) & & & $<0.01$ & $<0.01$ & $<0.01$ & $<0.01$ \\
\hline$A \times B$ & & & NS & NS & NS & NS \\
\hline
\end{tabular}

Pooled SEM - pooled standard error of mean.

A, B - values in columns with different letters differ highly significantly $(\mathrm{P}<0.01)$. NS - not significant.

${ }^{1}$ Data are means of 10 replicates. 
Table 9. Ca, P, pyridinoline and deoxypyridinoline concentrations in blood plasma of hens at 64 weeks of age ${ }^{1}$

\begin{tabular}{l|c|c|c|c}
\hline \multirow{2}{*}{\multicolumn{1}{c|}{ Item }} & \multicolumn{3}{|c|}{ Group } & \multirow{2}{*}{$\begin{array}{c}\text { Pooled } \\
\text { SEM }\end{array}$} \\
\cline { 2 - 4 } & $\begin{array}{c}\text { Leghorn } \\
\text { H-22 }\end{array}$ & $\begin{array}{c}\text { Sussex } \\
\text { S-66 }\end{array}$ & $\begin{array}{c}\text { RIR } \\
\text { R-11 }\end{array}$ & \\
\hline $\mathrm{P}(\mathrm{mmol} / \mathrm{l})$ & 1.55 & $1.30 \mathrm{~A}$ & $1.84 \mathrm{~B}$ & 0.09 \\
$\mathrm{Ca}(\mathrm{mmol} / \mathrm{l})$ & 4.58 & 4.26 & 4.62 & 0.08 \\
Pyridinoline (ng/ml) & 78.88 & 60.32 & 63.48 & 3.57 \\
Deoxypyridinoline $(\mathrm{ng} / \mathrm{ml})$ & 47.89 & 55.80 & 23.09 & 9.64 \\
\hline
\end{tabular}

Pooled SEM - pooled standard error of mean.

$\mathrm{a}, \mathrm{b}-$ values in rows with different letters differ significantly $(\mathrm{P}<0.05)$.

A, $\mathrm{B}$ - values in rows with different letters differ highly significantly $(\mathrm{P}<0.01)$.

${ }^{1}$ Data are means of 10 replicates.

\section{Discussion}

In our study, the chicken breed had an important impact mainly on the weight and diameter of the tested bones and the Seedor index. The RIR hens had the heaviest and greater diameter bones, certainly influenced by a greater body weight (Onbaşılar et al., 2016) than the Leghorn and the Sussex. Rayan et al. (2013) showed differences in weight and tibia bones weight between brown (Hy-Line Brown) and white (HyLine W-36) hens. Also Onbaşılar et al. (2016) found a difference in the tibia and femur bones weight and diameter in Lohmann Brown Classic (LB) and Lohmann LSL Classic (LW) hens. The LB birds had thicker and heavier bones than the LW. However, the authors did not find any difference in the length of studied bones which is confirmed by own studies. The RIR hens also had the highest Seedor index, which may be indicative of higher bone density and strength (Ogunwole et al., 2018). Our results show differences in bone characteristics between the layer breeds which may lead to a higher bone strength in some of the breeds. Many studies on mammals showed that the bone density is hereditary (Boskey et al., 1999), and genetic defects can weaken the bones. In case of the poultry, it was shown that the brown hens have denser and stronger bones than the white ones (Korver et al., 2004; Riczu et al., 2004; Habig and Distl, 2013), which is confirmed by our study.

Van Wyhe et al. (2012) write that the bone mineralization is strongly correlated with the bone structural strength, and consequently the bone breaking strength. According to the authors, there are genetic differences in mineralization and strength of long bones. On the other hand, Rayan et al. (2013) did not find significant differences in the calcium and phosphorus levels in tibia bones between Hy-Line W-36 and Hy-Line Brown. Likewise in our study, no effect of breed on the level of $\mathrm{CA}, \mathrm{Ca}$ and $\mathrm{P}$ in tibia was observed. CA and $\mathrm{P}$ in humerus were higher in Sussex hens compared to Leghorn hens. The higher $\mathrm{P}$ content contributed to the $\mathrm{Ca}: \mathrm{P}$ ratio, which was lower in Sussex compared to Leghorn and RIR hens. A difference in the Ca:P ratio was also noted in the femurs between RIR and Leghorn birds, although $\mathrm{Ca}$ and 
P were at a similar level in the studied breeds. It should be noted, however, that in our study the Ca:P ratio in the bones fell within the normal range of 2:1 (Thorp and Waddington, 1997; Ren et al., 2019).

Almeida Paz and Bruno (2006) write that minerals in bones usually are deposited in the period before egg laying, and the mineral density decreases as the egg production grows. Rayan et al. (2013) showed that the percent content of calcium and phosphorus in the tibia bones decreased with age of layer hens. In turn, Regmi et al. (2017) found higher ash content in the tibiae and humeri of layers at 72 compared to 56 weeks, which shows that bone mineralization increases with age. According to the authors, this leads to an increased stiffness of the bone accompanied by a decrease in toughness. In our study, age had a significant effect on increasing the level of ash, $\mathrm{Ca}$ and $\mathrm{P}$, and also on the $\mathrm{Ca}: \mathrm{P}$ ratio in the analysed bones up to 45 weeks of age. Humerus and tibia bone did not show differences in the crude ash and macroelements levels between the 64 th and the 45 th week of age. The femurs of 64-week-old hens contained more $\mathrm{Ca}$ than at week 45, which may suggest that long bones differ in their capacity to incorporate calcium with age. In general, however, the lack of large differences in bone mineralization between 45 and 64 weeks indicates that under normal management conditions, hens of the studied breeds may go through the production cycle without major weakening of the bones associated with the loss of calcium or phosphorus.

In our study we also determined blood $\mathrm{Ca}$ and $\mathrm{P}$ concentration as an indicator of the mineral balance associated directly with bone metabolism. Ca and $\mathrm{P}$ homeostasis is essential for optimal bone mineralization (Proszkowiec-Węglarz and Angel, 2013; Li et al., 2020) and for maintaining bone strength (Rath et al., 2000). Li et al. (2020) report that low serum phosphorus concentration leads to osteoclast activation, which increases bone resorption. In turn, pyridinoline and deoxypyridinoline are amino acids released from meshed bone structure when collagen is degraded during bone resorption (Liu et al., 2003; Regmi et al., 2017).

The obtained results indicate that in the 64th week of age, the RIR hens had the highest phosphorus level and the Sussex the lowest. In general, plasma P concentration in Sussex hens was lower than that observed in end-of-lay hens by other authors (Dobrzański et al., 2011; Świątkiewicz et al., 2015). However, Jing et al. (2018) reported that plasma or serum contain only a small part of total P deposited in the body, which is why changes in plasma $\mathrm{P}$ concentration may not necessarily reflect changes in the whole body. This is consistent with our study, because at 64 weeks we found no differences in crude ash or P content of the analysed bones between the breeds. No differences were observed between the studied breeds in the level of the other blood parameters.

Our study showed that hen breed had an effect mostly on morphometric indices of the bones such as bone weight and diameter, and the Seedor index (SI), while the age of birds had an effect on the bone mineralization level up to 45 weeks of age. The bone mineralization did not decrease in the studied breeds of hens at the end of the laying period.

It was also found that heavier birds (RIR) had greater diameter bones and a higher SI, but the content of ash and minerals in the bones of that breed was 
generally similar to the Leghorn and Sussex hens. RIR hens exhibited higher phosphorus plasma concentration compared to Sussex hens.

It would be appropriate to conduct a similar study with the same breeds under free-range and organic conditions.

\section{References}

A $1 \mathrm{meida}$ Paz I.C.L., Bruno L.D.G. (2006). Bone mineral density: review. Rev. Bras. Cienc. Avic., 8: 2.

A p p le gate T.J., Li 1 burn M.S. (2002). Growth of the femur and tibia of a commercial broiler line. Poultry Sci., 81: 1289-1294.

B o s k e y A.L., Wr i g h t T.M., B l a n k R.D. (1999). Collagen and bone strength. J. Bone Miner. Res., 14: 330-335.

Calik J., Krawczyk J., Św iątkiewicz S., Gąsior R., Wojtycza K., Połtowicz K., O brzut J., P u ch ała M. (2017). Comparison of the physicochemical and sensory characteristics of Rhode Island Red (R-11) capons and cockerels. Ann. Anim. Sci., 17, 3: 903-917.

Candelotto L., Stratmann A., Gebhardt-Henrich S.G., Rufener Ch., van de Braak T., Tos cano M.J. (2017). Susceptibility to keel bone fractures in laying hens and the role of genetic variation. Poultry Sci., 96: 3517-3528.

Cas e y - Trott T.M., Gu e rin M.T., S andil and s V., Torrey S., Wi d ow ski T.M. (2017 a). Rearing system affects prevalence of keel-bone damage in laying hens: a longitudinal study of four consecutive flocks. Poultry Sci., 96: 2029-2039.

Cas ey-Trott T.M., Korver D.R., Guerin M.T., S andilands V., Torrey S., Widow s k i T.M. (2017 b). Opportunities for exercise during pullet rearing, Part II: Long-term effects on bone characteristics of adult laying hens at the end-of-lay. Poultry Sci., 96: 2518-2527.

Cout and M., Cyr M., Deydier E., Guilet R., C l a stres P. (2008). Characteristics of industrial and laboratory meat and bone meal ashes and their potential applications. J. Hazard. Mater., $150,522-532$.

Damaziak K., Michalczuk M., Szara T., Marzec A., Niemiec J., Turek B. (2014). Effect of genotype on selected quality attributes of turkey bone. Eur. Poultry Sci., 78, DOI: 10.1399/ eps. 2014.12

Dobrzanski Z., Opalinski S., Hoffmann K., Bubel F., Pogoda-Sewerniak K. (2011). Effect of different feed phosphates on blood plasma mineral profile in laying hens. Electr. J. Pol. Agric. Univ., 14, www.ejpau.media.pl/volume14/issue4/art-15.html

Habig C., D ist 1 O. (2013). Evaluation of bone strength, keel bone status, plumage condition and quality of two layer lines kept in small group housing systems. Br. Poultry Sci., 54: 413-424.

He erkens J.L.T., De lezi e E., Rodenburg T.B., Kempen I., Zoons J., A mpe B., Tuyt t e n s F.A.M. (2016). Risk factors associated with keel bone and foot pad disorders in laying hens housed in aviary systems. Poultry Sci., 95: 482-488.

Jendral M.J., Korver D.R., Church J.S., Feddes J.J.R. (2008). Bone mineral density and breaking strength of White Leghorns housed in conventional, modified, and commercially available colony battery cages. Poultry Sci., 87: 828-837.

Ji ang S., Cui L., Sh i C., Ke X., Lu o J., H ou J. (2013). Effects of dietary energy and calcium levels on performance, egg shell quality and bone metabolism in hens. Vet. J., 198: 252-258.

Ji ang S., Wu X. L., Ji n M.L., Wang X.Z., Tang Q., S un Y.X., Cheng H.W. (2019). Pathophysiological characteristics and gene transcriptional profiling of bone microstructure in low calcium diet fed laying hens. Poultry Sci., 98: 4359-4368.

Jing M., Zha o S., R o giew ic z A., Sło miński B.A., Hous e J.D. (2018). Assessment of the minimal available phosphorus needs of laying hens: Implications for phosphorus management strategies. Poultry Sci., 97: 2400-2410.

Käppeli S., Gebhardt-Henrich S.G., Fröhllich E., Pfulg A., Stoffel M.H. (2011). Prevalence of keel bone deformities in Swiss laying hens. Brit. Poultry Sci., 52: 531-536. 
Kolaks hy a p a t i M., Flave l R.J., S i b a nd a T.Z., S c hneider D., We l ch M.C., Ruhnke I. (2019). Various bone parameters are positively correlated with hen body weight while range access has no beneficial effect on tibia health of free-range layers. Poultry Sci., 98: 6241-6250.

K orver D.R., S a und ers - B l a d e s J.L., N o d e a n K.L. (2004). Assessing bone mineral density in vivo: quantitative computed tomography. Poultry Sci., 83: 222-229.

Kraw c z y k J., O brzu t J., Ś w i ą t k i e w i c z S., C a li k J. (2019). The effect of slaughter age and the diet in the final growth phase of poulards on productivity and meat quality. Ann. Anim. Sci., 19: 499-516.

Kuźni a cka J., B anaszak M., A damski M. (2017). The analysis of meat and bone traits of Plymouth Rock cockerels and capons (P55) at different age. Poultry Sci., 96: 3169-3175.

Lay D.C., Fulton R.M., Hester P.Y., Karcher D.M., Kja er J.B., Mench J.A., Mullens B.A., N ewberry R.C., Nicol C.J., O'Sullivan N.P., Porter R.E. (2011). Hen welfare in different housing systems. Poultry Sci., 90: 278-294.

Li T., Xing G., Sha o Y., Zhang L., Li S., Lu L., Li u Z., Li a o X., Lu o X. (2020). Dietary calcium or phosphorus deficiency impairs the bone development by regulating related calcium or phosphorus metabolic utilization parameters of broilers. Poultry Sci., 99: 3207-3214.

L i u D., Ve it H.P., W i l s o n J.H., D e n b o w D.M. (2003). Maternal dietary lipids alter bone chemical composition, mechanical properties, and histological characteristics of progeny of Japanese quail. Poultry Sci., 82: 463-473.

Mabelebele M., Norris D., Siwendu N.A., NG'Ambi J.W., Alabi O.J., Mbajior$\mathrm{g} \mathrm{u}$ C.A. (2017). Bone morphometric parameters of the tibia and femur of indigenous and broiler chickens reared intensively. Appl. Ecol. Env. Res., 15: 1387-1398.

N a s r M.A.F., N i c o 1 C.J., W i 1 k in s L.J., M u r re 11 J. (2014). The effect of two non-steroidal antiinflammatory drugs on the mobility of laying hens with keel bone fractures. Vet. Anaesth. Analg., 42: 197-204.

Ne ijat M., Cas e y - Trott T.M., Robinson S., Wid ow ski T.M., Kiarie E. (2019). Effects of rearing and adult laying housing systems on medullary, pneumatic and radius bone attributes in 73-wk old Lohmann LSL lite hens. Poultry Sci., 98: 2840-2845.

Obrzut J., Krawczyk J., Calik J., Św iątkiewicz S. (2018). Meat quality of poulards obtained from three conserved breeds of hens. Ann. Anim. Sci., 18: 261-280.

Ogunwole O.A., A d e d e j i B.S., Olumide M.D., Mos uro A.O., A d e w e mi mo I.E. (2018). Effects of dietary supplemental ascorbic acid and cholecalciferol on bone characteristics of hens at the late laying stage. Int. J. Food Sci. Nutr. Eng., 8: 142-150.

Onbaş 1 lar E.E., Erdem E., Ünal N., Tunç A.S, Koc akaya A., Yaranoğlu B. (2016). Comparison of liver and bone health of two laying hen strains kept in different cage systems. Eur. Poultry Sci., 80, DOI: 10.1399/eps.2016.123.

P i ckel T., S chrader L., S c holz B. (2011). Pressure load on keel bone and foot pads in perching laying hens in relation to perch design. Poultry Sci., 90: 715-724.

Pros z k ow i e c - We g l a r z M., A n g e l R. (2013). Calcium and phosphorus metabolism in broilers: effect of homeostatic mechanism on calcium and phosphorus digestibility. J. Appl. Poultry Res., 22: 609-627.

Rath N.C., Huff G.R., Huff W.E., B a log J.M. (2000). Factors regulating bone maturity and strength in poultry. Poultry Sci., 79: 1024-1032.

R a y a n G.N., G a lal A., F a th i M.M., El-A t t a r A.H. (2013). Effect of layer breeder strain and age on tibia bone characteristics of chicks. J. Agric. Vet. Sci., 6: 111-124.

Regmi P., N el s on N., S te ibel J.P., A nders on K.E., Ka r cher D.M. (2016). Comparisons of bone properties and keel deformities between strains and housing systems in end-of-lay hens. Poultry Sci., 95: 225-2234.

Regmi P., Nels on N., Haut R.C., Orth M.W., Ka r cher D.M. (2017). Influence of age and housing systems on properties of tibia and humerus of Lohmann White hens: Bone properties of laying hens in commercial housing systems. Poultry Sci., 96: 3755-3762.

Ren Z., Sun W., Liu Y., Li Z., Han D., Cheng X., Yan J., Yang X. (2019). Dynamics of serum phosphorus, calcium, and hormones during egg laying cycle in Hy-Line Brown laying hens. Poultry Sci., 98: 2193-2200.

R i c zu C.M., S a und e r s - B l a d e s J.L., Yng ve s s on A.K.Y., R o b in s on F.E., Kor v er D.R. (2004). End-of-cycle bone quality in white- and brown-egg laying hens. Poultry Sci., 83: 375-383. 
Rodenburg T.B., Tuyttens F.A.M., de Reu K., Herman L., Z oon s J., S onck B. (2008). Welfare assessment of laying hens in furnished cages and non-cage systems: an on-farm comparison. Anim. Welfare, 17: 363-373.

Rodríguez-Navarro A.B., McCormack H.M., Fleming R.H., Álvarez-Lloret P., Romero-Pastor J., Domínguez Gasca N., Prozorov T., Dunn I.C. (2018). Influence of physical activity on tibial bone material properties in laying hens, J. Struct. Biol., 201: $36-45$.

Sosnówka-Czajka E., Skomorucha I., Muchacka R. (2017). Effect of organic productions system on the performance and meat and meat quality of two purebred slow-growing chicken breeds. Ann. Anim. Sci., 17: 119-1213.

S ouz a C., S antos T.C., M ura k a mi A.E., I w a k i L.C.V., M e 11 o J.F. (2017). Influence of graded levels of calcium and vitamin $\mathrm{K}$ in the diets of laying hens during the growing phase and their effects on the laying phase. J. Anim. Physiol. An. N., 101: 974-983.

Stratmann A., Fröhllich E.K.F., Gebhardt-Henrich S.G., Harlander-Matausc h e c k A., W ü r b e 1 H., T o s c a n o M.J. (2015). Modification of aviary design reduces incidence of falls, collisions and keel bone damage in laying hens. Appl. Anim. Behav. Sci., 165: 112-123.

Św i ątki ew icz S., Arczewska - Włosek A., Józefiak D. (2015). Bone quality, selected blood variables and mineral retention in laying hens fed with different dietary concentrations and sources of calcium. Livest. Sci., 181: 194-199.

Świ ątkiewicz S., Arczewska-Włosek A., Szczurek W., Calik J., Krawczyk J., Jó zefi a k D. (2018). The influence of selected feed additives on mineral utilisation and bone characteristics in laying hens. Ann. Anim. Sci., 18: 781-793.

T h o r p B.H., W a d d in g t o n D. (1997). Relationships between the bone pathologies, ash and mineral content of long bones in 35-day-old broiler chickens. Res. Vet. Sci., 62: 67-73.

Tomaszewska E., Kwiecień M., Muszyński S., Dobrowolski P., Kasperek K., B licharskiG., Jeżewska - Witkowska G., Grela E.R. (2017). Long-bone properties and development are affected by caponisation and breed in Polish fowls. Brit. Poultry Sci., 58: $312-318$.

Van Wyhe R.C., Applegate T.J., Lilburn M.S., Karcher D.M. (2012). A comparison of long bone development in historical and contemporary ducks. Poultry Sci., 91: 2858-2865.

W h i t e h e a d C.C. (2004). Overview of bone biology in the egg-laying hen. Poultry Sci., 83: 193-199. Wh it e h e a d C.C., F le m ing H. (2000). Osteoporosis in cage layers. Poultry Sci., 79: 1033-1041.

Wilkins L.J., McKinstry J.L., Avery N.C., Knowles T.G., Brown S.N., Tarlton J., $\mathrm{N}$ i c o 1 C.J. (2011). Influence of housing system and design on bone strength and keel bone fractures in laying hens. Vet. Rec., 169: 414.

Received: 15 IV 2020

Accepted: 17 XI 2020 